\title{
Synthesis of nano- $\mathrm{TiO}_{2}$ assisted by glycols and submitted to hydrothermal or conventional heat treatment with promising photocatalytic activity
}

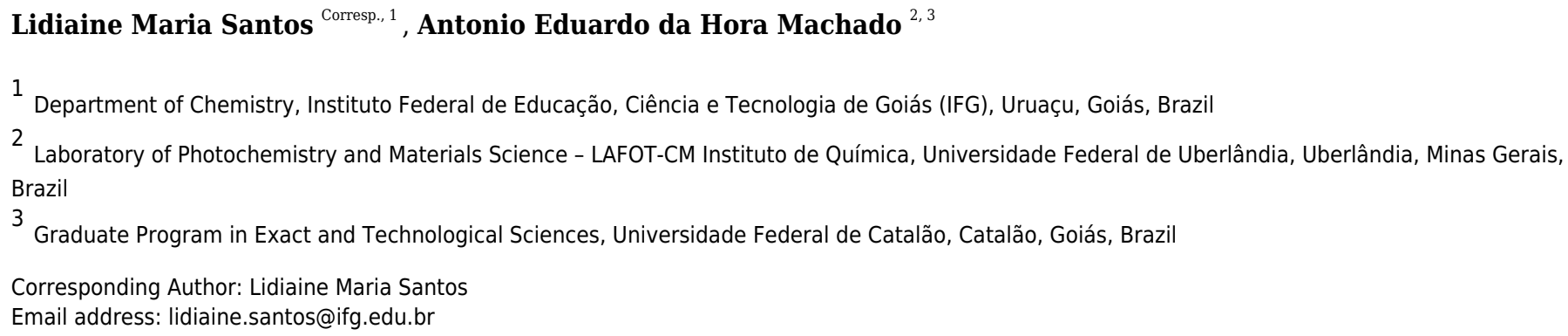

$\mathrm{TiO}_{2}$ nanoparticles were successfully synthesized by the sol-gel method employing different glycols (ethylene glycol, diethylene glycol or polyethylene glycol 300), which were heat-treated in conventional oven or by hydrothermal via, obtaining photocatalysts with particle sizes and distinct crystalline structures. HRTEM analyses showed that the oxides submitted to hydrothermal treatment featured spherical morphology, being formed by partially aggregated particles with sizes varying between 2 and $5 \mathrm{~nm}$. X-ray diffractograms and Raman spectroscopy confirm that anatase was predominant in all synthesized compounds, with presence of brookite phase for samples that received hydrothermal treatment or were synthesized in the presence of polyethylene glycol with heat treatment in conventional oven. The amount of brookite as well as the cell volume, deformation, network parameters and crystallinity were estimated by Rietveld refinement. The surface area and porosity of the materials were higher when the synthesis involved the use of hydrothermal treatment. These oxides are mesoporous with porosity between 14 and 31\%. The oxide synthesized in the presence of ethylene glycol with hydrothermal thermal treatment $\left(\mathrm{TiO}_{2} \mathrm{G} 1 \mathrm{HT}\right)$ exhibited the highest photocatalytic activity in terms of mineralization of azo-dye Ponceau 4R (C.I. 16255), under UV-Vis irradiation. This higher photocatalytic activity can be attributed to the formation of binary oxides composed by anatase and brookite and by its optimized morphological and electronic properties. 
1 Synthesis of nano- $\mathrm{TiO}_{2}$ assisted by glycols and

2 submitted to hydrothermal or conventional heat

3 treatment with promising photocatalytic activity

4

5

6

\section{Corresponding Author:}

Lidiaine M Santos ${ }^{1}$

Rua Formosa, Qd 28 e 29, Santana, Uruaçu, Goiás, 76400-000, Brazil

Email address: lidiaine.santos@ifg.edu.br 


\section{Synthesis of nano- $\mathrm{TiO}_{2}$ assisted by glycols and submitted to hydrothermal or conventional heat treatment with promising photocatalytic activity}

Lidiaine Maria Santos ${ }^{1}$, Antonio Eduardo da Hora Machado 2,3

37

${ }^{1}$ Instituto Federal de Educação, Ciência e Tecnologia de Goiás (IFG), Uruaçu, Goiás, Brazil

${ }^{2}$ Laboratory of Photochemistry and Materials Science - LAFOT-CM Instituto de Química,

${ }^{3}$ Graduate Program in Exact and Technological Sciences, Universidade Federal de Catalão,

Catalão, Goiás, Brazil.

43

Corresponding Author:

Lidiaine M Santos ${ }^{1}$

Rua Formosa, Qd 28 e 29, Santana, Uruaçu, Goiás, 76400-000, Brazil

Email address: 1idiaine.santos@ifg.edu.br

\section{Abstract}

$\mathrm{TiO}_{2}$ nanoparticles were successfully synthesized by the sol-gel method employing different glycols (ethylene glycol, diethylene glycol or polyethylene glycol 300), which were heat-treated in conventional oven or by hydrothermal via, obtaining photocatalysts with particle sizes and distinct crystalline structures. HRTEM analyses showed that the oxides submitted to hydrothermal treatment featured spherical morphology, being formed by partially aggregated particles with sizes varying between 2 and $5 \mathrm{~nm}$. X-ray diffractograms and Raman spectroscopy confirm that anatase was predominant in all synthesized compounds, with presence of brookite phase for samples that received hydrothermal treatment or were synthesized in the presence of polyethylene glycol with heat treatment in conventional oven. The amount of brookite as well as the cell volume, deformation, network parameters and crystallinity were estimated by Rietveld refinement. The surface area and porosity of the materials were higher when the synthesis involved the use of hydrothermal treatment. These oxides are mesoporous with porosity between 14 and $31 \%$. The oxide synthesized in the presence of ethylene glycol with hydrothermal thermal treatment $\left(\mathrm{TiO}_{2} \mathrm{G} 1 \mathrm{HT}\right)$ exhibited the highest photocatalytic activity in terms of mineralization of the azo-dye Ponceau 4R (C.I. 16255), under UV-Vis irradiation. This higher photocatalytic activity can be attributed to the formation of binary oxides composed by anatase and brookite and by its optimized morphological and electronic properties. 
69

70

71

72

73

74

75

76

77

78

79

80

81

82

83

84

85

86

87

88

89

90

91

92

93

94

95

96

97

98

99

100

101

102

103

104

105

106

107

108

\section{Introduction}

Titanium dioxide $\left(\mathrm{TiO}_{2}\right)$ is widely employed in technological applications, including solar energy conversion, chemical sensors for gases, environmental depollution and hydrogen production, among others (Machado et al., 2015; Riyapan et al., 2016). It is an n-type semiconductor, with band gap energy of the extended solid (bulk) in the ultraviolet region of approximately 3.20, 3.02 and $3.14 \mathrm{eV}$, respectively for anatase, rutile and brookite, the three natural polymorphs (Grätzel \& Rotzinger, 1985).

$\mathrm{TiO}_{2}$-based materials are the most investigated for photocatalytic application since the discovery by Fujishima e Honda (Fujishima \& Honda, 1972). It is one of the most commonly used semiconductor oxide for environmental photocatalysis, being of low toxicity, insoluble in water and stable to photo and chemical corrosion over a wide range of $\mathrm{pH}$ (Machado et al., 2012; Rekulapally et al., 2019). The photocatalytic process involves the electronic excitation from the valence (VB) to the conduction band (CB), when irradiated by ultraviolet light. This process generates charge carriers $\left(e^{-} / h^{+}\right.$pairs) that react with molecular oxygen and water, forming reactive oxygen species (ROS), such as superoxide radical ion $\left(\mathrm{O}_{2}{ }^{\circ}\right)$ and hydroxyl radical $\left(\mathrm{HO}^{\bullet}\right)$. These and other secondary-generated radicals promote the degradation of environmental pollutants (Machado et al., 2008; Muthamizhchelvan et al., 2020).

Anatase, the most active polymorph for photocatalytic applications, contains more defects due to its structure and acts as electron trap (Gupta \& Tripathi, 2011). Already in rutile, there is a high $e^{-} / h^{+}$recombination rate, which limits the photocatalytic response. On the other hand, the brookite photocatalytic activity seems to be related to the relative position of the electronic bands, where $\mathrm{CB}$ energy is $0.14 \mathrm{eV}$ more negative than that of anatase in anatase/brookite associations, favoring the photocatalytic processes (Kandiel et al., 2010; Patrocinio et al., 2015).

The physical and chemical properties of $\mathrm{TiO}_{2}$ depend on the arrangement of the crystalline phase, size and shape of the particles, surface area and crystallinity (Tan et al., 2015; El-Sheikh et al., 2017), parameters that can be controlled or adjusted during the synthesis process.

This oxide can be obtained by different synthetic routes (Ahmadi et al., 2015; Benetti et al., 2016; Hajizadeh-Oghaz, 2019; Kumar et al., 2019). The synthesis via sol-gel methodology can be improved by the use of reagents with long hydrophobic chains favoring the controlled formation of critical nuclei, leading to the obtaining of mesoporous particles in a nanometric scale (Wang et al., 2014; Darbandi \& Dickerson, 2016; El-Sheikh et al., 2017; Catauro et al., 2018). Crystallization is a necessary step for obtaining oxides with a defined structure, purity and desirable morphology. This process can occur either by conventional heat (He et al., 2014; Patrocinio et al., 2015) or by hydrothermal treatment (Kim \& Kwak, 2007; Qin et al., 2016).

The application of $\mathrm{TiO}_{2}$ as a photocatalyst has some disadvantages that can be overcome. The main disadvantage is the high band gap, followed by the relatively high recombination rate of the charge carriers, this last reducing considerably the quantum yield of the photocatalytic processes (Kumar \& Devi, 2011; Feng et al., 2012; Jaiswal et al., 2015; França et al., 2016).

The existence of junction between different phases of the same semiconductor, as for example in anatase/brookite (A/B) or anatase/rutile (A/R) mixtures (Cihlar et al., 2015), results in 
synergistic effects that leads to a more efficient separation of the $e^{-} / h^{+}$pairs, reducing the charge recombination rate. Consequently, while the electrons are trapped in one of the crystalline phases, the holes present in the VB have greater chance to oxidize organic matter, enhancing the photocatalytic activity (Yang et al., 2013; Shao et al., 2014; Zhang et al., 2020).

In the present study, photocatalysts based on $\mathrm{TiO}_{2}$ were synthesized by the sol-gel method. The influence of the use of different structural molds (ethylene glycol, diethylene glycol or polyethylene glycol 300) as well as the effect of thermal treatments by conventional or hydrothermal routes, was evaluated on their photocatalytic activity, and structural optical and morphological properties. The photocatalytic activity was evaluated through the degradation of the azo-dye Ponceau 4R, chosen due to its industrial application and undesirable effects on the environment and human health (Oliveira et al., 2012; European Food 2020). The results presented here aim to provide new insights into the synthesis of $\mathrm{TiO}_{2}$-based photocatalysts with different crystalline phases and the influence of preparation conditions on the photocatalytic properties of these systems.

\section{Materials \& Methods}

\section{Preparation of different $\mathrm{TiO}_{2}$ photocatalysts}

All chemicals were of analytical or HPLC grade and were used as received. Ultrapure water obtained from an Elix 5 Milli-Q ${ }^{\circledR}$ water purification system was employed in all experiments. $\mathrm{TiO}_{2}$ samples were synthesized by the sol-gel method, using different glycols (ethylene glycol, diethylene glycol or polyethylene glycol 300) (Sigma Aldrich), and heat treatment in a conventional oven or hydrothermal system.

The $\mathrm{TiO}_{2} \mathrm{Gx}$ photocatalyst was obtained from the mixture, under magnetic stirring, of $10 \mathrm{~mL}$ of Ti (IV) isopropoxide (Aldrich, 97\%) and $50 \mathrm{~mL}$ of glycol (where $\mathrm{x}=1$ when $886 \mathrm{mmol}$ of ethylene glycol (Vetec, 99.5\%) were used, $x=2$ for $527 \mathrm{mmol}$ diethylene glycol (Vetec, 99.5\%), and $\mathrm{x}=3$ when polyethylene glycol 300 (Fluka) was used). After 2 hours of stirring, a mixture containing $10 \mathrm{~mL}$ of ultrapure water and $90 \mathrm{ml}$ of acetone (Synth, 99.5\%) was added to the suspension and kept under stirring for 2 hours. The white precipitate was separated with the aid of a centrifuge ( $9000 \mathrm{rpm}$ for 20 minutes), followed by washing several times with ethanol to remove residues of glycol, followed by washing three times with distilled water.

For the preparation of heat-treated photocatalysts in a conventional oven $\left(\mathrm{TiO}_{2} \mathrm{GxM}\right)$, after washing the powder was dried at $70^{\circ} \mathrm{C}$ under reduced pressure and sintered at $400^{\circ} \mathrm{C}$ for 2 hours. After centrifugation and washing the decanted oxide prepared using hydrothermal treatment, $\mathrm{TiO}_{2} \mathrm{GxHT}$, was submitted to the hydrothermal reactor under a pressure of approximately 13.8 bar at $200^{\circ} \mathrm{C}$ for 4 hours. Subsequently, it was dried at $70^{\circ} \mathrm{C}$ for 24 hours. 
149

150

151

152

153

154

155

156

157

158

159

160

161

162

163

164

165

166

167

168

169

170

171

172

173

174

175

176

177

178

179

180

181

182

183

184

185

186

187

188

\section{Characterization of the photocatalysts}

High resolution electronic transmission images were obtained using a Jeol, JEM-2100, Thermo scientific Transmission Electron Microscope. The particle size and spacing between crystalline planes were calculate with the free software "ImageJ".

X-ray diffraction analyses (XRD) using a Shimadzu XRD600 powder diffractometer operating at $40 \mathrm{kV}$ and $120 \mathrm{~mA}$, employing $\mathrm{Cu} \mathrm{K} \alpha(\lambda=1,54148 \AA)$ radiation. The diffractograms were collected between $10^{\circ} \leq 2 \theta \leq 90^{\circ}$ under a rate of $0.5^{\circ} \mathrm{min}^{-1}$. Crystalline silicon was used as the diffraction standard. X-ray diffratogram of the oxides were refined by the method of Rietveld using the FullProf software, with fitting criteria (Factor S - Goodness of Fit) was employed as the ratio between the weight factor $\left(\mathrm{R}_{\mathrm{wp}}\right)$ and the expected factor $\left(\mathrm{R}_{\text {exp }}\right)$, which should be closer to 1 . The fit parameters can be found in the Supplemental Information (Table S1).

$\mathrm{N}_{2}$ adsorption-desorption isotherms were obtained using an ASAP 2010 analyzer (Micrometrics). The specific area were analyzed using the Brunauer, Emmett and Teller (BET) model and the Barrett-Joyner-Halenda (BJH) model for the porous volume (Barrett, Joyner \& Halenda, 1951).

Raman spectra were acquired at room temperature using a Bruker spectrometer model RFS 100/S, samples were excited at $1064 \mathrm{~nm}$ with laser operating at $100 \mathrm{~mW}$. Diffuse reflectance spectra of the synthesized oxides were acquired using an UV-1650PC Spectrometer (Shimadzu), at room temperature and potassium bromide was used as reference. The band gap energy being estimated by the Kubelka-Munk function (Patterson, Shelden \& Stockton, 1977).

\section{Photocatalytic activity}

In all photocatalytic assays, $100 \mathrm{mg} \mathrm{L}^{-1}$ of the catalyst was added to $31 \mathrm{mg} \mathrm{L}^{-1}$ dye Ponceau 4R (trisodium (8Z)-7-oxo-8-[(4-sulfonatonaphthalen-1-yl)hydrazinylidene]naphthalene-1,3disulfonate, CI 16255, Sigma-Aldrich, 75\%) aqueous solution $(\mathrm{pH}=6.9)$ under magnetic stirring. The experimental setup was previously described in detail (Oliveira et al., 2012). Information about the radiation source and experimental data were available in (Machado et al., 2008; Santos et al., 2015).

The photocatalytic system was kept at $40 \pm 2{ }^{\circ} \mathrm{C}$ and under stirring for 30 minutes in the dark to reach the adsorption equilibrium. Control measurements in the dark were performed and in the absence of a catalyst to evidence the role of $\mathrm{TiO}_{2}$ in the photochemical reaction. Aliquots were taken at 20 minutes intervals, filtered and analyzed by spectrophotometry, following the discoloration at $507 \mathrm{~nm}$ using a Shimadzu spectrophotometer model 1650PC and by Total Organic Carbon (TOC) measurements, using a Shimadzu TOC-VCPH/CPN analyzer.

\section{Results \& Discussion}

TEM images evidence that the heat-treated oxides in a conventional oven and by hydrothermal via are made up of approximately spherical nanoparticles (Fig. 1 A-D). For the 
189

190

191

192

193

194

195

196

197

198

199

200

201

202

203

204

205

206

207

208

209

210

211

212

213

214

215

216

217

218

219

220

221

222

223

224

225

226

227

228

material produced after processing in a conventional oven, the formation of agglomerates was more pronounced than after hydrothermal treatment. The estimated particle size from the HRTEM images (Fig. $1 \mathrm{E}-\mathrm{H}$ ) were $10 \mathrm{~nm}, 2 \mathrm{~nm}, 3 \mathrm{~nm}$ e $4 \mathrm{~nm}$ respectively for the oxides $\mathrm{TiO}_{2} \mathrm{G} 1 \mathrm{M}, \mathrm{TiO}_{2} \mathrm{G} 1 \mathrm{HT}, \mathrm{TiO}_{2} \mathrm{G} 2 \mathrm{HT}$ e $\mathrm{TiO}_{2} \mathrm{G} 3 \mathrm{HT}$. The sample calcined in a conventional oven, $\mathrm{TiO}_{2} \mathrm{G} 1 \mathrm{M}$, presented the largest particle size, probably due the coalescence process by diffusion of smaller (more unstable) particles, favoring the formation of agglomerates. The formation of smaller, although stable, particles was observed after hydrothermal treatment, which tends to produce particles with larger surface areas. The use of different glycols in the synthesis also influenced the particle size due the increase in the carbon chain $(\mathrm{G} 1<\mathrm{G} 2<\mathrm{G} 3)$, which resulted in slightly larger particles.

HRTEM images suggest high crystallinity, mainly for the sample treated in a conventional oven. The spacing between crystalline planes, for all samples, was estimated as being $0.35 \mathrm{~nm}$, corresponding to the (101) plan of the anatase phase, indicating that in all cases this is the preferential growth plan for nanoparticles. The presence of crystallographic planes referring to the brookite and rutile crystalline phases were not verified through the images. In the case of brookite, the spacing between the crystallographic planes, of $0.38 \mathrm{~nm}$, corresponding to the (120) and (111) planes, is very close to the spacing of the anatase $(0.35 \mathrm{~nm})$ causing ambiguity (Kobayashi et al., 2007). These plans, in the presence of higher anatase content, are overlaid by the (101) plan. The spacing between the $0.29 \mathrm{~nm}$ crystallographic planes, corresponding to the (121) plane, characteristic of the brookite, was not observed (Di Paola, Bellardita \& Palmisano, 2013)

\section{[Fig]}

Figure 1 TEM and HRTEM images of mesoporous $\mathrm{TiO}_{2}$ : (A, E) $\mathrm{TiO}_{2} \mathrm{G} 1 \mathrm{M},(\mathrm{B}, \mathrm{F}) \mathrm{TiO}_{2} \mathrm{G} 1 \mathrm{HT}$, (C, G) $\mathrm{TiO}_{2} \mathrm{G} 2 \mathrm{HT},(\mathrm{D}, \mathrm{H}) \mathrm{TiO}_{2} \mathrm{G} 3 \mathrm{HT}$.

The XRD data (Fig. 2) confirm that all samples are composed mostly of nanocrystals of anatase, with the (101) phase preferably exposed. In the case of HT processing at $200^{\circ} \mathrm{C}$ for $4 \mathrm{~h}$, the presence of crystalline anatase phases and traces of brookite was observed, being confirmed by the presence of peaks at $2 \theta$ equal to $25.38^{\circ}(101)$ and $30.80^{\circ}(121)$, respectively. Under the treatment conditions to which these materials were submitted, the formation of the rutile phase was not observed. The formation of the brookite phase was probably a crucial factor for the inhibition of the transformation of anatase into rutile.

Rietveld analyses of the diffractograms (Fig. S1) confirm the decrease in crystallite size for the oxides obtained after hydrothermal heat treatment (HT), which agrees with the HRTEM images. These quantitative data also confirm the greater presence of brookite phase in samples submitted to hydrothermal treatment. Besides that, it is observed that the percentage of the brookite phase remains practically constant even with the use of different glycols in the synthesis process. Already for materials prepared with heat treatment in a conventional oven, it turns out that the use of different glycols leads to greater deformations only for the $\mathrm{TiO}_{2} \mathrm{G} 3 \mathrm{M}$ sample, 
229

230

231

232

233

234

235

236

237

238

239

240

241

242

243

244

245

246

247

248

249

250

251

252

253

254

255

256

257

258

259

260

261

262

263

264

265

266

267

268

where polyethylene glycol was used in the synthesis, causing the formation of $17.47 \%$ brookite phase (Tay et al., 2013).

The $\mathrm{TiO}_{2} \mathrm{G} 3 \mathrm{HT}$ sample had a higher portion of brookite when compared to the $\mathrm{TiO}_{2} \mathrm{G} 3 \mathrm{M}$ sample, because since brookite is featured by its low symmetry, its formation is more efficient under mild conditions such as shorter period and lower preparation temperature, as occurs in hydrothermal treatment conditions (Lin et al., 2012).

\section{[Fig]}

Figure $2 \mathrm{X}$-ray diffraction patterns of the studied photocatalysts: (A) $\mathrm{TiO}_{2} \mathrm{G} 1 \mathrm{HT}$; (B) $\mathrm{TiO}_{2} \mathrm{G}_{2} \mathrm{HT}$ and (C) $\mathrm{TiO}_{2} \mathrm{G} 3 \mathrm{HT}$, (D) $\mathrm{TiO}_{2} \mathrm{G} 1 \mathrm{M}$; (E) $\mathrm{TiO}_{2} \mathrm{G} 2 \mathrm{M}$ and (F) $\mathrm{TiO}_{2} \mathrm{G} 3 \mathrm{M}$.

The formation of mesoporous structures was confirmed by $\mathrm{N}_{2}$ adsorption-desorption isotherms (Fig 3). Isotherms follow the type III for samples with $100 \%$ anatase phase $\left(\mathrm{TiO}_{2} \mathrm{G} 1 \mathrm{M}\right.$ e $\left.\mathrm{TiO}_{2} \mathrm{G} 2 \mathrm{M}\right)$. The other samples, with brookite content, have type IV with a pronounced hysteresis loop of types $\mathrm{H} 3$ and $\mathrm{H} 4$, according to the IUPAC classification. This suggests that these materials are mesoporous solids formed by agglomerated or aggregated particles (Gregg \& Sing, 1982). The presence of brookite causes a decrease in the average pore diameters, suggesting that the presence of structural defects influences the adsorption capacity and porosity of the material. The values of surface area and porosity of these materials are presented in Table 1 .

\section{[Fig]}

Figure $3 \mathrm{~N}_{2}$-adsorption-desorption isotherms obtained for the photocatalysts.

Table 1 Morphologic and electronic parameters to oxides synthesized. [Table]

The diffuse reflectance spectra, expressed in terms of $F(R)$ vs. photon energy $(E)$, are presented in Fig. 4. The indirect band gap value $\left(E_{g}\right)$ was obtained by extrapolating the linear segment to the $\mathrm{X}$ axis, Table 1 . However, a simple inspection of the spectra suggests that the band gap values calculated in this way calculated in this way are deviated from the actual values, since the radiation absorption is not canceled $\left(E<E_{g}\right)$, except from the point where $\mathrm{F}(\mathrm{R}) \rightarrow 0$. This suggests the existence of permitted states with energies lower than the estimated $E_{g}$, that is, $E_{g(\text { real })}<E_{g}$. Thus, considering the lower threshold of the conduction band, which occurs when $\mathrm{F}(\mathrm{R}) \rightarrow 0$, that is, states with energies less than or equal to the energy associated with this threshold, are prohibited. In view of this, $E_{g(\text { real })}$ was also calculated (Table 1). Based on this information, it appears that all photocatalysts absorb radiation more intensely in the near-UV region. However, these photocatalysts, despite the high band gap energies, have significant photocatalytic activity in the visible region, as suggest the estimated values of $E_{g(\text { real })}$. The $\mathrm{TiO}_{2} \mathrm{G} 1 \mathrm{HT}, \mathrm{TiO}_{2} \mathrm{G} 2 \mathrm{HT}$ and $\mathrm{TiO}_{2} \mathrm{G} 1 \mathrm{M}$ photocatalysts show a radiation absorption profile shifted 
269

270

271

272

273

274

275

276

277

278

279

280

281

282

283

284

285

286

287

288

289

290

291

292

293

294

295

296

297

298

299

300

301

302

303

304

305

306

307

308

to the visible region, with $E<E_{g}$, being therefore able to uptake photons in a large range of wavelengths. Related to these factors, the high surface area, crystallinity and mixture of crystalline phases are added, which end up favoring the photocatalytic potential of these oxides.

The electronic properties of the particles change significantly by reducing their size. Thus, new properties can be expected in nanoparticles when compared to bulk (Hodes, 2007). The variation of energy as a function of size promotes the quantum confinement and is characterized by an increase in the indirect band gap energy $\left(E_{g}\right)$, as can be seen for $\mathrm{TiO}_{2} \mathrm{G} 1 \mathrm{HT}$, which has smaller particle and crystallite sizes, as estimated by HRMET and DRX analyses, and $E_{g}(3.30$ $\mathrm{eV})$ greater than that of the extended solid $\left(3.20 \mathrm{eV}\right.$ for $\left.\mathrm{TiO}_{2}\right)($ Kumar \& Devi, 2011).

\section{[Fig]}

Figure 4 Diffuse reflectance spectra of the $\mathrm{TiO}_{2}$ photocatalysts. Inset: Diffuse reflectance spectra of the samples.

The catalysts were also evaluated using Raman spectroscopy (Fig. 5). All samples exhibit vibration modes typical of anatase $\left(3 \mathrm{E}_{\mathrm{g}}+2 \mathrm{~B}_{1 \mathrm{~g}}+\mathrm{A}_{1 \mathrm{~g}}\right)$. $\mathrm{A}_{1 \mathrm{~g}}$ symmetry mode was not visualized, probably due the overlap with the band corresponding to the second mode, of $\mathrm{B}_{1 \mathrm{~g}}$ symmetry (Iliev et al., 2013; Fang et al., 2015). A slight change in the signs is observed depending on the type of heat treatment used (Fig 5 - Inset). The bands referring to samples thermally treated by hydrothermal route are broader than those observed for the calcined oxides in a conventional oven. This broadening can be directly correlated to the concentration of oxygen vacancies on the photocatalysts, as previously shown by Parker e Siegel (Parker \& Siegel, 1990). Thus, Raman analysis indicates that the synthesis of oxides treated by the hydrothermal route, induces the formation of oxygen vacancies on the oxide surface, increasing the system disorder.

\section{[Fig]}

Figure 5 Raman spectra, at room temperature, for the synthesized $\mathrm{TiO}_{2}$ photocatalysts. Inset: Expanded normalized Raman spectra between 100 and $200 \mathrm{~cm}^{-1}$ in the main $\mathrm{E}_{\mathrm{g}}$ peak region attributed to the broadening of the band according to the type of heat treatment.

\section{Photocatalytic activity}

The photocatalytic activity of the different synthesized oxides was evaluated in terms of the degradation of the azo-dye Ponceau 4R. The control experiment, in the absence of any photocatalyst, reveals extremely low levels of dye discoloration (4.0\%) and mineralization (13\%) after 140 minutes of irradiation (Fig. S2). The degradation efficiency presented by the different photocatalysts is summarized in Table 2 .

Table 2 Mineralization, Langmuir-Hinshelwood kinetics and discoloration of the P4R azo-dye mediated by the prepared oxides. 
309

310

311

312

313

314

315

316

317

318

319

320

321

322

323

324

325

326

327

328

329

330

331

332

333

334

335

336

337

338

339

340

341

342

343

344

345

346

347

348

\section{[Table]}

The oxides thermally treated by hydrothermal via were more efficient than conventional heat treatment in promoting the degradation and mineralization of the dye under study. Calcination in a conventional oven led to an increase in the crystallinity of the materials, as seen by the XRD data, and a decrease in the surface area, which ended up compromising the photocatalytic activity of these oxides.

The photocatalytic performance exhibited by the samples synthesized in the presence of different glycols and thermally treated by hydrothermal via can be attributed to the coexistence of anatase and brookite the high surface area, mesoporosity, and more appropriate particle sizes. Crystalline materials with smaller particle sizes are more likely to exhibit expressive photocatalytic properties (Ohno et al., 2001).

Although the $\mathrm{TiO}_{2} \mathrm{G} 3 \mathrm{M}$ photocatalyst also presents itself as a mixture of polymorphs anatase and brookite, it did not show significant photocatalytic activity, probably related to its smaller surface area.

The increase in photocatalytic activity of samples that present anatase and brookite can be explained by the synergism between these polymorphs. Although anatase and brookite present a very close $E_{g}$ (Machado et al., 2012; Patrocinio et al., 2015), theoretical calculations have shown that the energies of the conduction and valence bands of anatase phase are slightly lower than the corresponding energy levels of brookite ( $L i$ et al., 2008), suggesting a certain ease of migration of electrons from brookite to anatase. Thus, the holes are more available for oxidation reactions. In addition, the energy barrier between these polymorphs will tend to hinder the recombination among charge carriers. Therefore, with an extended life span, holes in the brookite valence band have a greater chance to oxidize organic matter, while electrons "trapped" in anatase may favor reduction reactions, leading to an increase in the photocatalytic activity ( $L i$, Ishigaki \& Sun, 2007; Patrocinio et al., 2015).

A complex degradation mechanism is expected in heterogeneous photocatalysis (Hoffmann et al., 1995; Ahmed et al., 2010). The reactions occur initially at the solid-solution interface and involve reactive species generated on the surface of the excited photocatalyst or by direct interaction between the excited photocatalyst and the substrate (Oliveira et al., 2012; Santos et al., 2015). In the degradation under study, the discoloration of the dye is probably related to the homolytic scission of the azo group. Hydroxyl radicals $(\mathrm{HO} \bullet)$, formed in the solid-solution interface, may be responsible for this process (Kumar \& Devi, 2011). Table 2 presents data on the percentage of discoloration in the reactions mediated by the oxides synthesized in this study. The best performances occurred using oxides submitted to hydrothermal treatment.

The mineralization process follows a Langmuir-Hinshelwood kinetics (Hoffmann et al., 1995), being of pseudo-first order in relation to the dye, as show in Fig. 6 . The rate constants are listed in Table 2. 


\section{9 [Fig]}

350 Figure 6 P4R mineralization kinetics using different photocatalysts: $\mathrm{TiO}_{2} \mathrm{G} 1 \mathrm{HT}(\mathrm{A}), \mathrm{TiO}_{2}$

351

352

353

354

355

356

357

358

359

360

361

362

363

364

365

366

367

368

369

370

371

372

373

374

375

376

377

378

379

380

381

382

383

384

385 G2HT (B), $\mathrm{TiO}_{2}$ G3HT (C), $\mathrm{TiO}_{2} \mathrm{G} 1 \mathrm{M}(\mathrm{D}), \mathrm{TiO}_{2} \mathrm{G} 2 \mathrm{M}(\mathrm{E})$ and $\mathrm{TiO}_{2} \mathrm{G} 3 \mathrm{M}$ (F). Inset: Absorption spectrum of the dye solution as a function of the irradiation time $(\Delta t=20 \mathrm{~min})$, during the action of the $\mathrm{TiO}_{2} \mathrm{G} 1 \mathrm{HT}$ photocatalyst.

In these assays, it was found that only $4.0 \%$ of the dye was adsorbed in the photocatalyst (Fig. S2), suggesting that the observed mechanism occurs mainly through the photodegradation of organic matter, certainly by the action of reactive oxygen species (ROS), such as $\mathrm{HO}^{\bullet}$ or $\mathrm{O}_{2}{ }^{\bullet}$, with the predominant action of the $\mathrm{HO}^{\bullet}$ radicals, a very strong oxidizing agent (standard reduction potential of $\mathrm{HO} / \mathrm{H}_{2} \mathrm{O} 2.38 \mathrm{~V}_{\text {vs. }} \mathrm{NHE}$ ) (Hoare, 1985). Accordingly, and based on the characterization of the photocatalysts, we can propose a mechanism, shown in equations (1-9) which must occur at the solid-solution interface, where $\mathrm{TiO}_{2}(\mathrm{~A})$ is the anatase polymorph and $\mathrm{TiO}_{2}$ (B) is the brookite polymorph. As result of the photoexcitation of the catalyst (1), the $e^{-/ h^{+}}$ pairs are generated; recombination processes (2) compete with the electron trapping in the polymorph anatase (3) and holes in the brookite polymorph (4 and 5), generating the reactive species responsible for the degradation of the dye (5, 6 and 7$)$. In the valence and conduction bands, the oxidation (8) and reduction (9) reactions occur, respectively, resulting in degradation products.

$$
\begin{aligned}
& \mathrm{TiO}_{2}(A+B)+h v(\mathrm{UV}) \rightarrow \mathrm{TiO}_{2}\left(e_{c b}{ }^{-}+h_{v b}{ }^{+}\right) \\
& e^{-}(c b)+h^{+}(v b) \rightarrow \mathrm{TiO}_{2}(A+B)+h v(\text { or heat }) \\
& \mathrm{TiO}_{2}(A)\left(e_{c b}{ }^{-}\right)+\mathrm{O}_{2} \rightarrow \mathrm{TiO}_{2}+\mathrm{O}_{2}{ }^{-} \\
& \mathrm{TiO}_{2}(\mathrm{~B})\left(h_{v b}{ }^{+}\right)+\mathrm{H}_{2} \mathrm{O} \rightarrow \mathrm{TiO}_{2}+\mathrm{H}^{+}+\mathrm{HO}^{\bullet} \\
& \mathrm{TiO}_{2}(\mathrm{~B})\left(h_{v b}{ }^{+}\right)+\mathrm{OH}^{-} \rightarrow \mathrm{TiO}_{2}+\mathrm{HO}^{\bullet} \\
& \mathrm{O}_{2}{ }^{-\bullet}+\mathrm{H}^{+} \rightarrow \mathrm{HO}_{2}{ }^{\bullet} \\
& \mathrm{P} 4 \mathrm{R}+\mathrm{OH}^{\bullet} \rightarrow \text { Degradation products } \\
& P 4 R+h_{v b}{ }^{+} \rightarrow \text { product oxidation } \\
& P 4 R+e_{c b}{ }^{-} \rightarrow \text { product reduction }
\end{aligned}
$$

The $\mathrm{TiO}_{2} \mathrm{G} 1 \mathrm{HT}$ oxide, present the best photocatalytic performance $\left(\mathrm{k}_{\text {app }}=5.9 \times 10^{3} \mathrm{~min}^{-1} ; \mathrm{R}\right.$ $=0.9824$ ), because the availability of reactive species becomes proportionally higher as the concentration of the dye decreases, since the concentration of these species is practically constant during the photocatalytic process (França et al., 2016). Therefore, P4R undergo fragmentation at the beginning of the reaction (Fig 6 - Inset), which should favor a faster mineralization.

Analyzing the spectrum presented in the Inset of Fig 6, it can be seen that at the end of the photocatalytic process, the band centered at $500 \mathrm{~nm}$, referred to an electronic transition with a 
major component $\pi \rightarrow \pi^{*}$ (Oliveira et al., 2012), involving the naphthalenic structures and the azo group, associated with the coloring of the dye, decreases significantly. The formed products should not present new or significant absorption bands in the analyzed region, suggesting that the degradation not only induces a quick discoloration of the dye (Table 2), as they should also cause a significant fragmentation of the dye structure, whose fragments should not absorb significantly in the monitored region of the electromagnetic spectrum.

The coexistence of anatase and brookite in the $\mathrm{TiO}_{2}$ synthesized with different glycols and treated by a hydrothermal via at low temperature, minimized the recombination rate of the $e^{-/ h^{+}}$ pairs, thus allowing the holes to be available for oxidation reactions. In addition, the correlation of physical and chemical factors, such as high surface areas and porosity, high photon absorption capacity in the UV-visible region and crystallinity considerably improved the photocatalytic activity of these oxides.

\section{Conclusions}

In this study, we present the preparation of $\mathrm{TiO}_{2}$ mesoporous nanoparticles using the sol-gel method with different glycols as structural molds. The use of ethylene glycol associated to further hydrothermal heat treatment proved to be the most effective way to obtain nanoparticles with improved photocatalytic activity. The results showed that materials submitted to hydrothermal heat treatment presented smaller particles and greater porosity, with formation of approximately spherical nanoparticles and with sizes up to $5 \mathrm{~nm}$ and formation of a binary mixture of anatase and brookite phases. The use of different glycols influenced the size of the particles, promoting the formation of smaller particles. The existence of a junction between different phases of the same semiconductor, accompanied by a decrease in the size of the particles, favored the charge transfer processes and contributed to the delay of the recombination processes, significantly improving the photocatalytic activity, verified by the degradation of the azo-dye Ponceau 4R under UV-Vis light irradiation. This type of photocatalyst that can harness both UV and visible light is a promising candidate for applications in photochemistry, sensors and solar cells, which has motivated us to develop oxides and nanocomposites based on $\mathrm{TiO}_{2}$ with a wide spectrum of applications.

\section{Acknowledgements}

The authors are thankful to Centro de Tecnologias Estratégicas do Nordeste (CETENE) and Laboratório Multiusuário de Microscopia de Alta Resolução (LABMIC) for the analysis of specific surface area and HRTEM images. 
424

425

426

427

428

429

430

431

432

433

434

435

436

437

438

439

440

441

442

443

444

445

446

447

448

449

450

451

452

453

454

455

456

457

458

459

460

461

\section{References}

Ahmadi K, Ziabari AA, Mirabbaszadeh K, Shal AA. 2015. Synthesis and characterization of $\mathrm{ZnO} / \mathrm{TiO}_{2}$ composite core/shell nanorod arrays by sol-gel method for organic solar cell applications. Bulletin of Materials Science 38:617-623 DOI: 10.1007/s12034-015-0898-8.

Ahmed S, Rasul MG, Martens WN, Brown R, Hashib MA. 2010. Heterogeneous photocatalytic degradation of phenols in wastewater: A review on current status and developments.

Desalination 261:2-18 DOI: 10.1016/j.desal.2010.04.062.

Barrett EP, Joyner LG, Halenda PP. 1951. The determination of pore volume and area distributions in porous substances. I. Computations from nitrogen isotherms. Journal of the American Chemical Society 73:373-380.

Benetti D, Dembele KT, Benavides J, Zhao H, Cloutier S, Concina I, Vomiero A, Rosei F. 2016. Functionalized multi-wall carbon nanotubes $/ \mathrm{TiO}_{2}$ composites as efficient photoanodes for dye sensitized solar cells. Journal of Materials Chemistry C 4:3555-3562 DOI: 10.1039/c6tc00800c.

Catauro M, Tranquillo E, Dal Poggetto G, Pasquali M, Dell'Era A, Ciprioti SV. 2018. Influence of the heat treatment on the particles size and on the crystalline phase of $\mathrm{TiO}_{2}$ synthesized by the sol-gel method. Materials 11:2364-2375 DOI: 10.3390/ma11122364.

Cihlar J, Kasparek V, Kralova M, Castkova K. 2015. Biphasic anatase-brookite nanoparticles prepared by sol-gel complex synthesis and their photocatalytic activity in hydrogen production. International Journal of Hydrogen Energy 40:2950-2962 DOI: 10.1016/j.ijhydene.2015.01.008.

Darbandi M, Dickerson JH. 2016. Nanoscale engineering of $\mathrm{TiO}_{2}$ nanoparticles: Evolution of the shape, phase, morphology, and facet orientation. Materials Letters 180:212-218 DOI: 10.1016/j.matlet.2016.05.109.

Di Paola A, Bellardita M, Palmisano L. 2013. Brookite, the least known $\mathrm{TiO}_{2}$ photocatalyst. Catalysts 3:36-73 DOI: 10.3390/catal3010036.

El-Sheikh SM, Khedra TM, Hakkib A, Ismaila AA, Badawy WA, Bahnemann DW. 2017. Visible light activated carbon and nitrogen co-doped mesoporous $\mathrm{TiO}_{2}$ as efficient photocatalyst for degradation of ibuprofen. Separation and Purification Technology 173:258-268 DOI: 10.1016/j.seppur.2016.09.034. 
462 European Food Safety Authority (EFSA); Scientific Opinion on the Re-evaluation of Ponceau 463 4R (E 124) as a Food Additive. Available at

464 http://www.efsa.europa.eu/en/scdocs/scdoc/1328.htm (accessed March 2020).

465

466

467

468

469

470

471

472

473

474

475

476

477

478

479

480

481

482

483

484

485

486

487

488

489

490

491

492

493

494

495

496

497

498

499

500

501

Feng H, Zhang MH, Yu LE. 2012. Hydrothermal synthesis and photocatalytic performance of metal-ions doped $\mathrm{TiO}_{2}$. Applied Catalysis A-General 413:238-244 DOI:

10.1016/j.apcata.2011.11.014.

Fang H, Zhang CX, Liu L, Zhao YM, Xu HJ. 2015. Recyclable three-dimensional Ag nanoparticle-decorated $\mathrm{TiO}_{2}$ nanorod arrays for surface-enhanced Raman scattering. Biosensors \& Bioelectronics 64:434-441 DOI: 10.1016/j.bios.2014.09.053.

França MD, Santos LM, Silva TA, Borges KA, Silva VM, Patrocinio AOT, Trovó AG, Machado AEH. 2016. Efficient mineralization of paracetamol using the nanocomposite $\mathrm{TiO}_{2} / \mathrm{Zn}$ (II) phthalocyanine as photocatalyst. Journal of the Brazilian Chemical Society 26:1094-1102 DOI: 10.5935/0103-5053.20160007.

Fujishima A, Honda K. 1972. Electrochemical photolysis of water at a semiconductor electrode. Nature, 238:37-+.

Grätzel M, Rotzinger FP. 1985. The influence of the crystal lattice structure on the conduction band energy of oxides of titanium(IV). Chemical Physics Letters 118:474-477 DOI:

https://doi.org/10.1016/0009-2614(85)85335-5.

Gregg SJ, Sing KSW. 1982. Adsorption, surface area and porosity. London: Academic Press,

Gupta SM, Tripathi M. 2011. A review of $\mathrm{TiO}_{2}$ nanoparticles. Physical Chemistry 56:1639-1657 DOI: $10.1007 / \mathrm{s} 11434-011-4476-1$.

Hajizadeh-Oghaz, M. 2019. Synthesis and characterization of Nb-La co-doped $\mathrm{TiO}_{2}$ nanoparticles by solgel process for dye-sensitized solar cells. Ceramics International 45:69947000 DOI: $10.1016 /$ j.ceramint.2018.12.200.

He F, Ma F, Li JL, Li T, Li GX. 2014. Effect of calcination temperature on the structural properties and photocatalytic activities of solvothermal synthesized $\mathrm{TiO}_{2}$ hollow nanoparticles. Ceramics International 40:6441-6446 DOI: 10.1016/j.ceramint.2013.11.094.

Hoare JP. 1985. Standard potentials in aqueous solution, ed. Bard AJ, Parsons R, Jordan J. New York, 63-64.

PeerJ Mat. Sci. reviewing PDF | (MATSCI-2020:09:53207:1:1:NEW 13 Jan 2021) 
502 Hodes G. 2007. When small is different: some recent advances in concepts and applications of

503 nanoscale phenomena. Advance Materials 19:639-655 DOI: 10.1002/adma.200601173.

504

505 Hoffmann MR, Martin ST, Choi WY, Bahnemann DW. 1995. Environmental applications of

506 semiconductor photocatalysis. Chemical Reviews 95:69-96.

507

508 Iliev MN, Hadjiev VG, Litvinchuk AP. 2013. Raman and infrared spectra of brookite $\left(\mathrm{TiO}_{2}\right)$ :

509 Experiment and theory. Vibrational Spectroscopy 64:148-152 DOI:

510 10.1016/j.vibspec.2012.08.003.

511

512 Jaiswal R, Bharambe J, Patel N, Dashora A, Kothari DC, Miotello A. 2015. Copper and Nitrogen

513 co-doped $\mathrm{TiO}_{2}$ photocatalyst with enhanced optical absorption and catalytic activity. Applied

514 Catalysis B-Environmental 168:333-341 DOI: 10.1016/j.apcatb.2014.12.053.

515

516 Kandiel TA, Feldhoff A, Robben L, Dillert R, Bahnemann DW. 2010. Tailored titanium dioxide

517 nanomaterials: Anatase nanoparticles and brookite nanorods as highly active photocatalysts.

518 Chemistry of Materials 22:2050-2060 DOI: 10.1021/cm903472p.

519

520 Kobayashi M, Petrykin VV, Kakihana M. 2007. One-step synthesis of $\mathrm{TiO}_{2}$ (B) nanoparticles

521 from a water-soluble titanium complex. Chemical Materials 19:5373-5376 DOI:

522 10.1021/cm071370q.

523

524

Kim DS, Kwak SY. 2007. The hydrothermal synthesis of mesoporous $\mathrm{TiO}_{2}$ with high

525 crystallinity, thermal stability, large surface area, and enhanced photocatalytic activity. Applied

526

527

528 Catalysis A-General 323:110-118 DOI: 10.1016/j.apcata.2007.02.010.

529

Kumar SG, Devi LG. 2011. Review on modified $\mathrm{TiO}_{2}$ photocatalysis under UV/Visible light:

530

531

532 Kumar RA, Yechuri G, Kumar K, Babu BR, Rajesh, C.H. 2019. Mn modified mesoporous $\mathrm{TiO}_{2}$ 533 particles: synthesis, characterization and photovoltaic application. Journal of Electronic

534 Materials 48:5075-5079 DOI: 10.1007/s11664-019-07312-5.

535

536

537 selected results and related mechanisms on interfacial charge carrier transfer dynamics. Journal of Physical Chemistry A 115:13211-13241 DOI: 10.1021/jp204364a.

538

Li JG, Ishigaki T, Sun XD. 2007. Anatase, brookite, and rutile nanocrystals via redox reactions under mild hydrothermal conditions: Phase-selective synthesis and physicochemical properties. Journal of Physical Chemistry C 111:4969-4976 DOI: 10.1021/jp0673258. 
540 Li W, Liu C, Zhou Y, Bai Y, Feng X, Yang Z, Lu L, Lu X, Chan K-Y. 2008. Enhanced

541 photocatalytic activity in anatase/ $\mathrm{TiO}_{2}$ (B) core-shell nanofiber. The Journal of Physical

542 Chemistry C 112:20539-20545 DOI: 10.1021/jp808183q.

543

544 Lin H, Li L, Zhao M, Huang X, Chen X, Li G, Yu R. 2012. Synthesis of high-quality brookite $545 \mathrm{TiO}_{2}$ single-crystalline nanosheets with specific facets exposed: tuning catalysts from inert to 546 highly reactive. Journal of the American Chemical Society. 134:8328-8331 DOI:

547 10.1021/ja3014049.

548

549

550

551

552

553

554

555

556

557

558

559

560

561

562

563

564

565

566

567

568

569

570

571

572

573

574

575

576

577 Parker JC, Siegel RW. 1990. Calibration of the Raman-Spectrum to the Oxygen Stoichiometry of 578 Nanophase $\mathrm{TiO}_{2}$. Applied Physics Letters 57:943-945 DOI: 10.1063/1.104274.

Machado AEH, Santos LM, Borges KA, Batista PS, Paiva VAB, Müller Jr P S, Oliveira DFM, França MD. 2012. Potential applications for solar photocatalysis: from environmental remediation to energy conversion. In: Babatunde EB, ed. Solar Radiation. Rijeka: InTech, 339 378.

Machado AEH, Santos LM, Borges KA, Silva TA, Borges MF, Machado WA, Caixeta BP, França MD, Oliveira SM, Trovó AG, Patrocínio AOT. 2015. Applications of mesoporous ordered semiconductor materials - Case study of $\mathrm{TiO}_{2}$. In: Bello R. ed. Solar Radiation Applications Rijeka: InTech, 87-118.

Machado AEH, Franca MD, Velani V, Magnino GA, Velani HMM, Freitas FS, Müller PS, Sattler C, Schmucker A. 2008. Characterization and evaluation of the efficiency of $\mathrm{TiO}_{2} / \mathrm{Zinc}$ Phthalocyanine nanocomposites as photocatalysts for wastewater treatment using solar irradiation. International Journal of Photoenergy 2008:1-13 DOI: 10.1155/2008/482373.

Muthamizhchelvan C, Ponnusamy S, Harish S, Navaneethan M, Santhi K. 2020. Synthesis and characterization of $\mathrm{TiO}_{2}$ nanorods by hydrothermal method with different $\mathrm{pH}$ conditions and their photocatalytic activity. Applied Surface Science 500:1-6 DOI:

10.1016/j.apsusc.2019.144058.

Ohno T, Sarukawa K, Tokieda K, Matsumura M. 2001. Morphology of a $\mathrm{TiO}_{2}$ photocatalyst (Degussa, P-25) consisting of anatase and rutile crystalline phases. Journal of Catalysis 203:8286 DOI: $10.1006 /$ jcat.2001.3316.

Oliveira DFM, Batista PS, Müller PS, Velani V, Franca MD, De Souza DR, Machado AEH. 2012. Evaluating the effectiveness of photocatalysts based on titanium dioxide in the degradation of the dye Ponceau 4R. Dyes and Pigments 92:563-572 DOI: 10.1016/j.dyepig.2011.06.007. 579 
580 Patrocinio AOT, Schneider J, Franca MD, Santos LM, Caixeta BP, Machado AEH, Bahnemann

581

582

583

584

585

586

587

588

589

590

591

592

593

594

595

596

597

598

599

600

601

602

603

604

605

606

607

608

609

610

611

612

613

614

615

616

617

618

619
DW. 2015. Charge carrier dynamics and photocatalytic behavior of $\mathrm{TiO}_{2}$ nanopowders submitted to hydrothermal or conventional heat treatment. Rsc Advances 5:70536-70545 DOI: 10.1039/C5RA13291F.

Patterson EM, Shelden CE, Stockton BH. 1977. Kubelka-Munk optical properties of a barium sulfate white reflectance standard. Applied Optics 16:729-732 DOI: 10.1364/AO.16.000729.

Qin Y, Hu Z, Lim BH, Chang WS, Chong KK, Zhang P, Zhang H. 2016. Sol-hydrothermal synthesis of $\mathrm{TiO}_{2}: \mathrm{Sm}^{3+}$ nanoparticles and their enhanced photovoltaic properties. Journal of Alloys and Compounds 686:803-809 DOI: 10.1016/j.jallcom.2016.06.179.

Riyapan S, Zhang Y, Wongkaew A, Pongthawornsakun B, Monnier JR, Panpranot J. 2016.

Preparation of improved $\mathrm{Ag}-\mathrm{Pd} / \mathrm{TiO}_{2}$ catalysts using the combined strong electrostatic adsorption and electroless deposition methods for the selective hydrogenation of acetylene. Catalysis Science \& Technology 6:5608-5617 DOI: 10.1039/C6CY00121A.

Rekulapally R, Murthy Chavali LN, Idris MM, Singh S. 2019. Toxicity of $\mathrm{TiO}_{2}, \mathrm{SiO}_{2}, \mathrm{ZnO}$, $\mathrm{CuO}, \mathrm{Au}$ and $\mathrm{Ag}$ engineered nanoparticles on hatching and early nauplii of Artemia sp. PeerJ 6:1-16 DOI 10.7717/peerj.6138

Santos LM, Machado WA, França MD, Borges KA, Paniago RM, Patrocínio AOT, Machado AEH. 2015. Structural characterization of Ag-doped $\mathrm{TiO}_{2}$ with enhanced photocatalytic activity. RSC Advances 5:103752-103759 DOI: 10.1039/c5ra22647c.

Shao D, Sun H, Xin G, Lian J, Sawyer S. 2014. High quality ZnO-TiO 2 core-shell nanowires for efficient ultraviolet sensing. Applied Surface Science 314:872-876 DOI:

10.1016/j.apsusc.2014.06.182.

Tan Z, Sato K, Ohara S. 2015. Synthesis of layered nanostructured $\mathrm{TiO}_{2}$ by hydrothermal method. Advanced Powder Technology 26:296-302 DOI: 10.1016/j.apt.2014.10.011.

Tay QL, Liu XF, Tang YX, Jiang ZL, Sum TC, Chen Z. 2013. Enhanced photocatalytic hydrogen production with synergistic two-phase anatase/brookite $\mathrm{TiO}_{2}$ nanostructures. Journal of Physical Chemistry C 117:14973-14982 DOI: 10.1021/jp4040979.

Zhang Q, Qian J, Chen Z, Chen F, Li X, Lu X. 2020. Biotemplating synthesis of N-doped twodimensional $\mathrm{CeO}_{2} \mathrm{eTiO}_{2}$ nanosheets with enhanced visible light photocatalytic desulfurization. Journal of Alloys and Compounds 815:1-11 DOI: 10.1016/j.jallcom.2019.152326. 
620 Wang L, Cai Y, Song LY, Nie W, Zhoua Y, Chen P. 2014. High efficient photocatalyst of 621 spherical $\mathrm{TiO}_{2}$ particles synthesized by a sol-gel method modified with glycol. Colloids and 622 Surfaces A: Physicochemical and Engineering Aspects 461:195-201 DOI:

623 10.1016/j.colsurfa.2014.07.050.

624

625 Yang J, Zhang X, Liu H, Wang C, Liu S, Sun P, Wang L, Liu Y. 2013. Heterostructured $626 \mathrm{TiO}_{2} / \mathrm{WO}_{3}$ porous microspheres: Preparation, characterization and photocatalytic properties. 627 Catalysis Today 201:195-202 DOI: 10.1016/j.cattod.2012.03.008.

628

629 


\section{Figure 1}

TEM and HRTEM images of mesoporous $\mathrm{TiO}_{2}:(\mathrm{A}, \mathrm{E}) \mathrm{TiO}_{2} \mathrm{GlM},(\mathrm{B}, \mathrm{F}) \mathrm{TiO}_{2} \mathrm{GlHT},(\mathrm{C}, \mathrm{G})$ $\mathrm{TiO}_{2} \mathrm{G} 2 \mathrm{HT}$, (D, H) $\mathrm{TiO}_{2} \mathrm{G} 3 \mathrm{HT}$. 
A

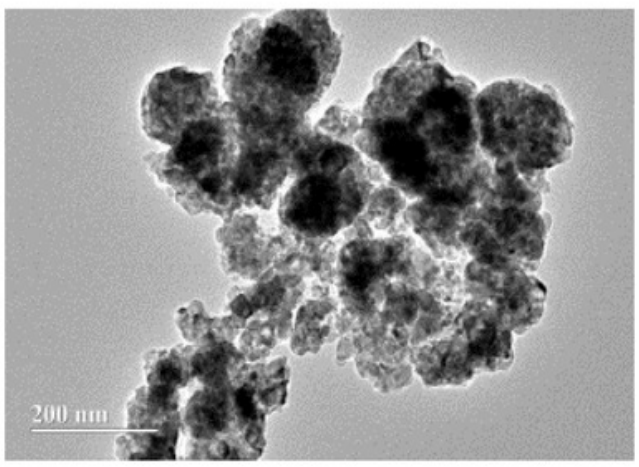

B

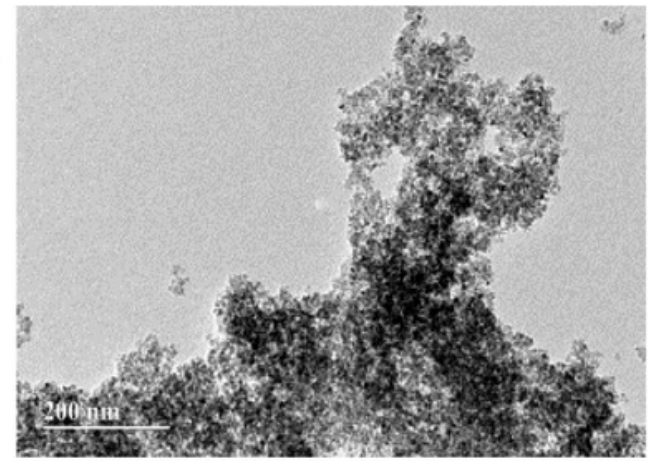

C

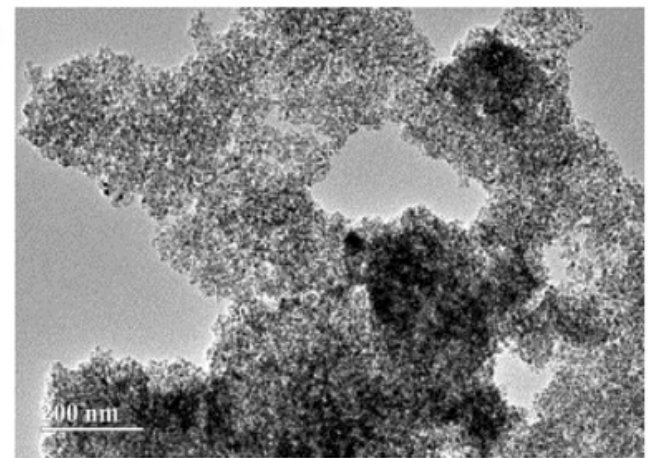

D

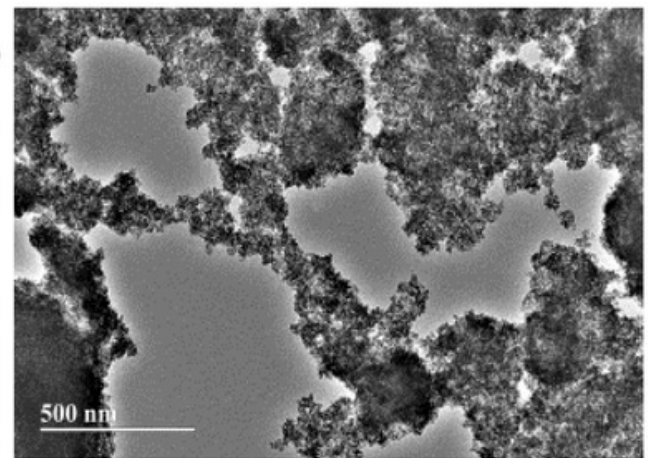

$\mathbf{E}$

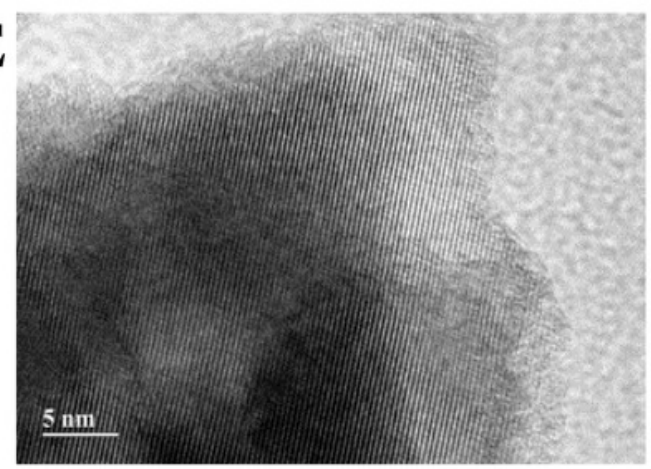

$\mathbf{F}$

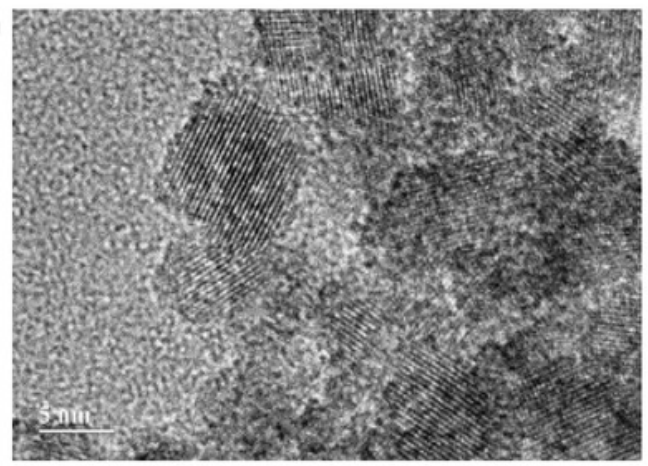

G

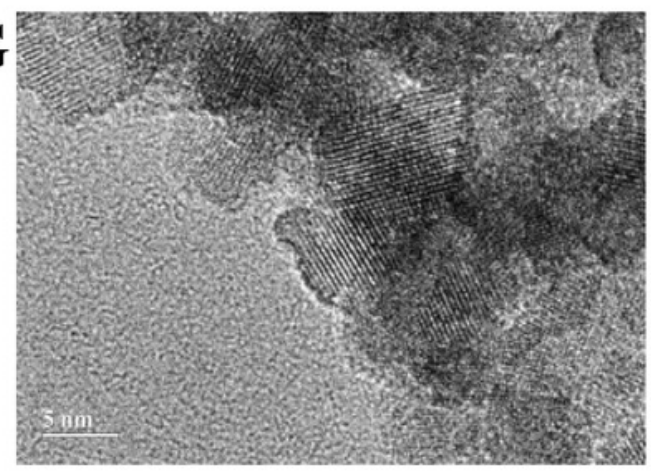

$\mathbf{H}$

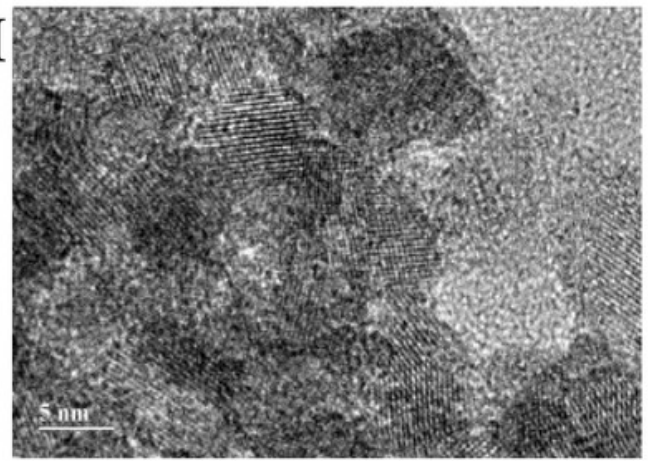


Figure 2

X-ray diffraction patterns of the studied photocatalysts: (A) $\mathrm{TiO}_{2} \mathrm{G} 1 \mathrm{HT}$; (B) $\mathrm{TiO}_{2} \mathrm{G} 2 \mathrm{HT}$ and (C) $\mathrm{TiO}_{2} \mathrm{G} 3 \mathrm{HT}$, (D) $\mathrm{TiO}_{2} \mathrm{G} 1 \mathrm{M}$; (E) $\mathrm{TiO}_{2} \mathrm{G} 2 \mathrm{M}$ and (F) $\mathrm{TiO}_{2} \mathrm{G} 3 \mathrm{M}$.

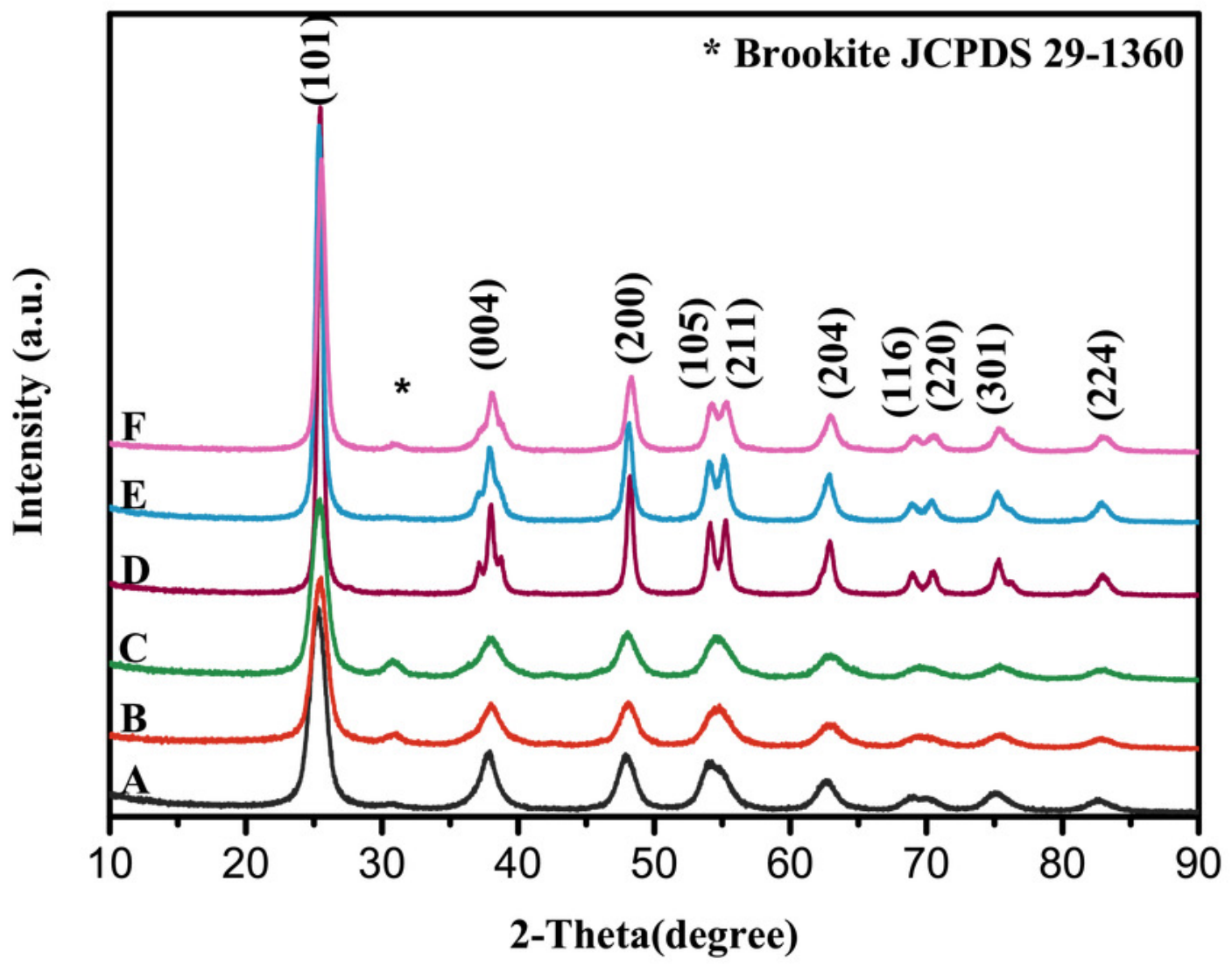


Figure 3

$\mathrm{N}_{2}$-adsorption-desorption isotherms obtained for the photocatalysts.

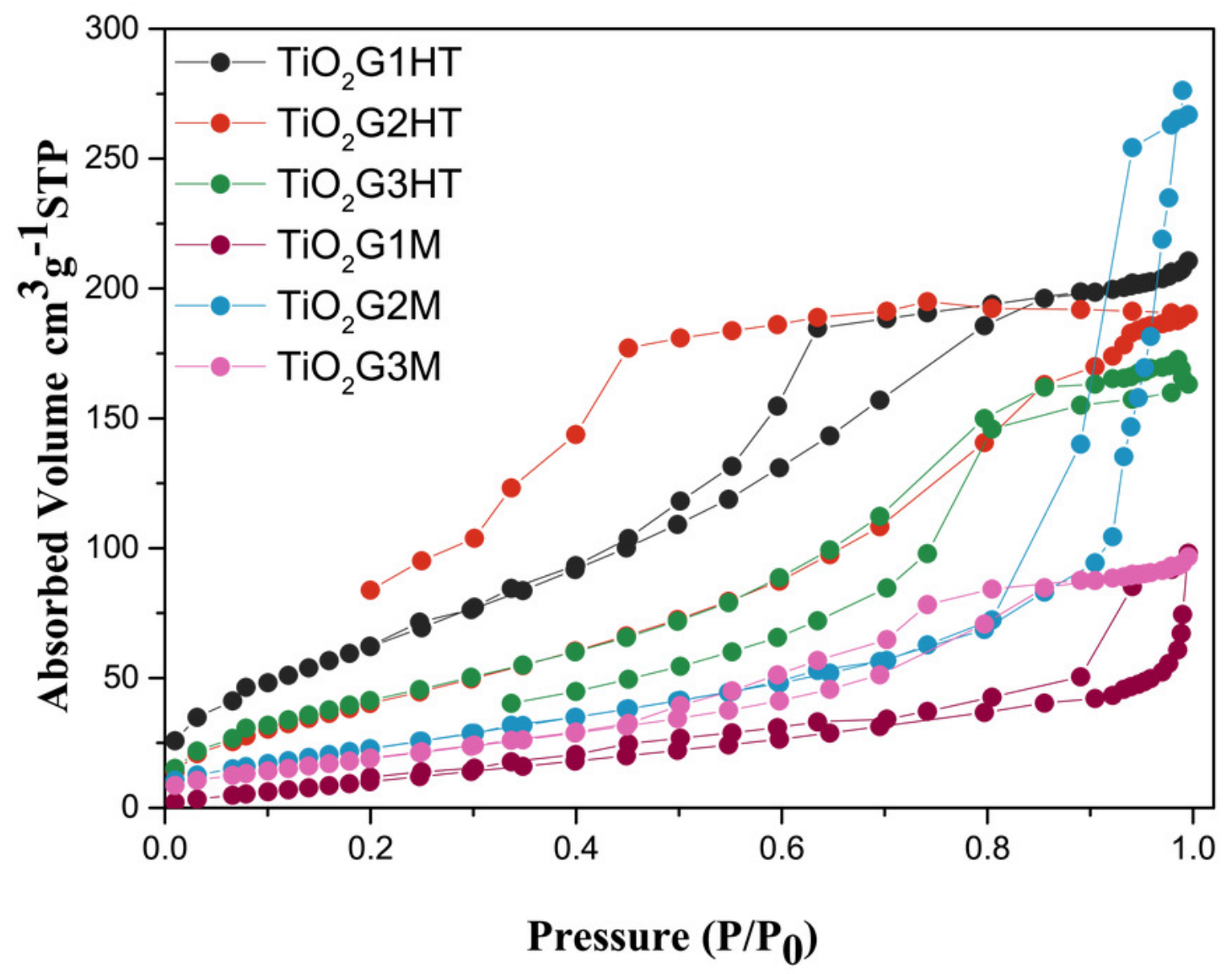


Figure 4

Diffuse reflectance spectra of the $\mathrm{TiO}_{2}$ photocatalysts. Inset: Diffuse reflectance spectra of the samples.

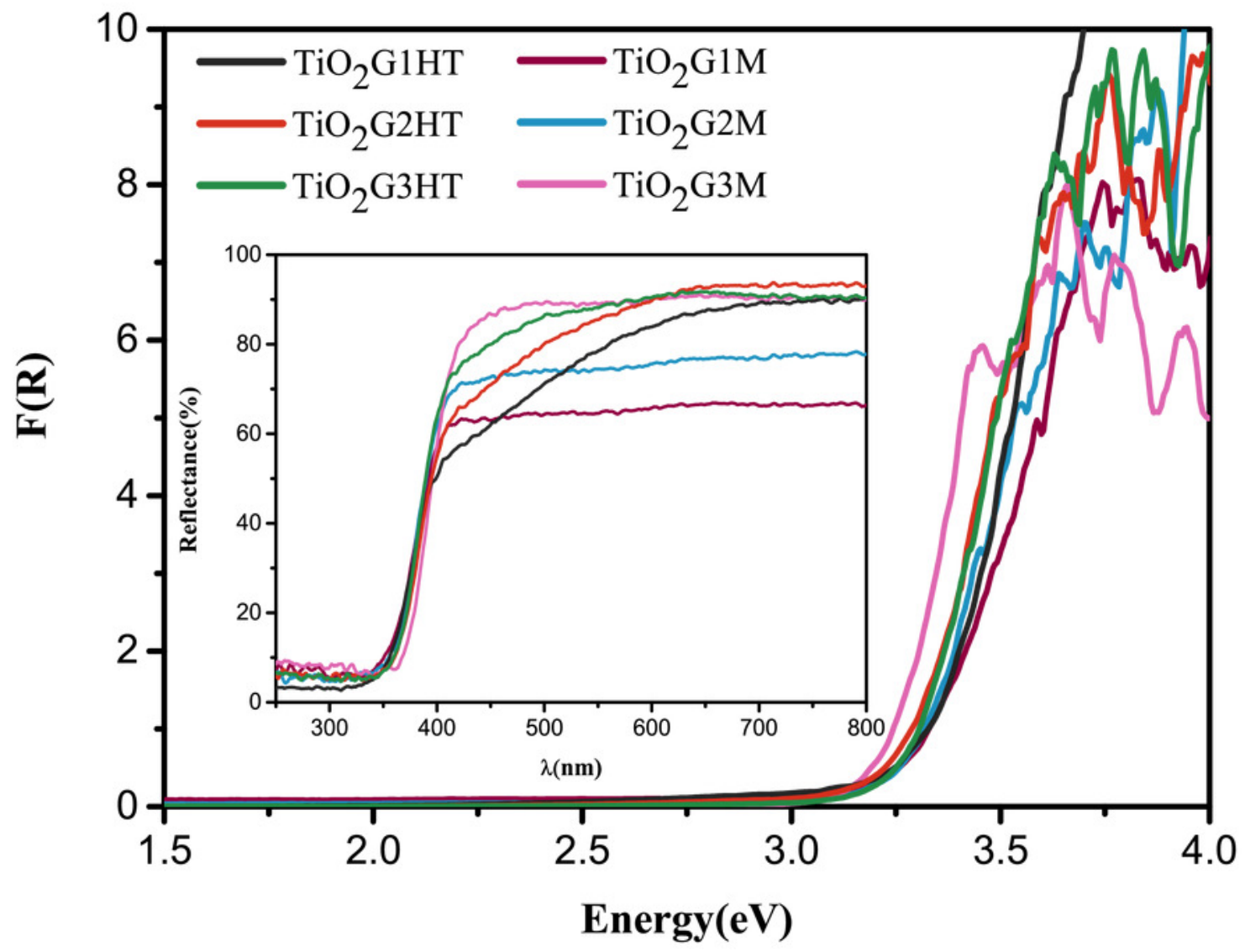


Figure 5

Raman spectra, at room temperature, for the synthesized $\mathrm{TiO}_{2}$ photocatalysts. Inset:

Expanded normalized Raman spectra between 100 and $200 \mathrm{~cm}^{-1}$ in the main $\mathrm{E}_{\mathrm{g}}$ peak region attributed to the broadening of the band according to $t$

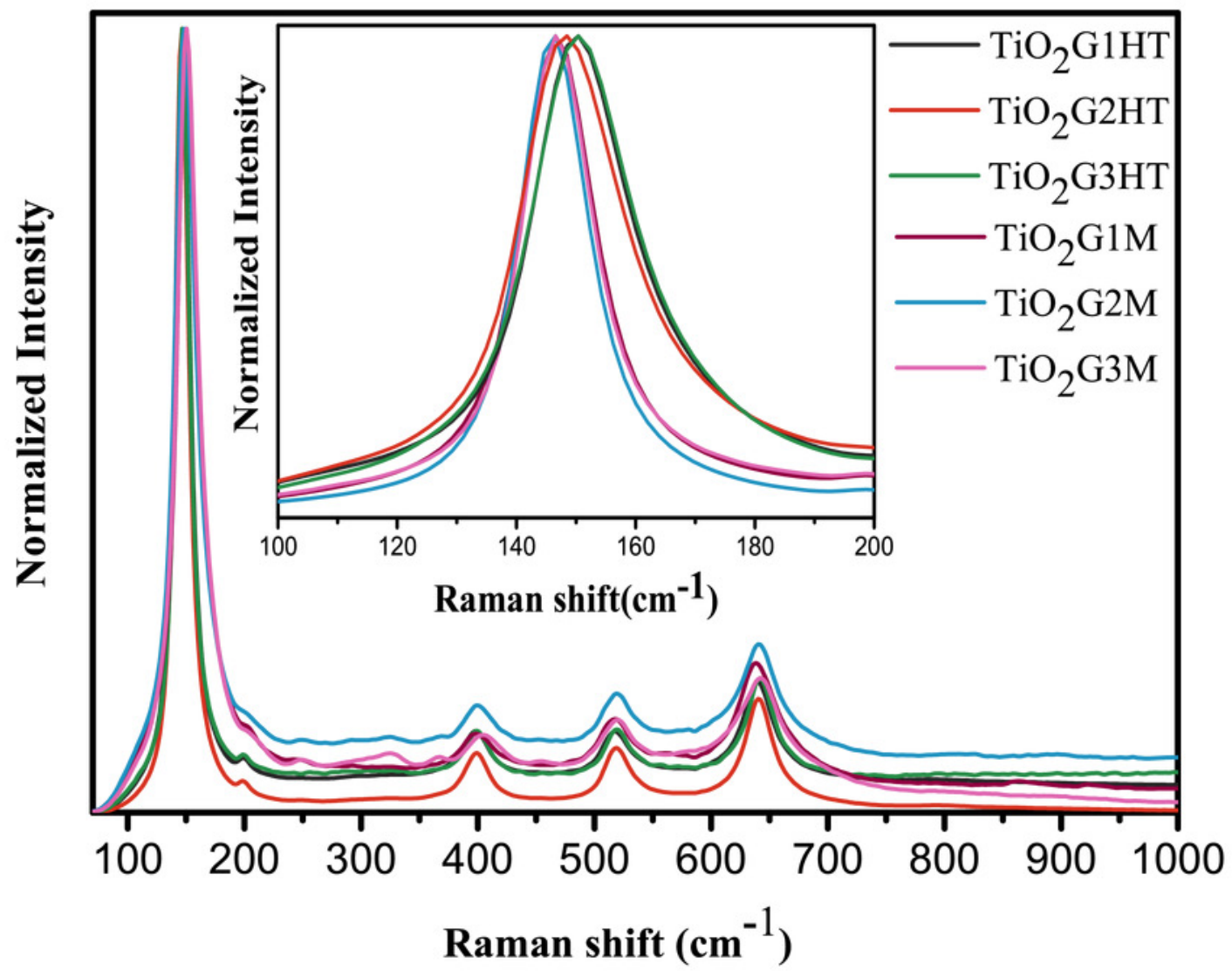


Figure 6

P4R mineralization kinetics using different photocatalysts: $\mathrm{TiO}_{2} \mathrm{G} 1 \mathrm{HT}(\mathrm{A}), \mathrm{TiO}_{2} \mathrm{G} 2 \mathrm{HT}(\mathrm{B})$, $\mathrm{TiO}_{2} \mathrm{G} 3 \mathrm{HT}(\mathrm{C}), \mathrm{TiO}_{2} \mathrm{G} 1 \mathrm{M}(\mathrm{D}), \mathrm{TiO}_{2} \mathrm{G} 2 \mathrm{M}(\mathrm{E})$ and $\mathrm{TiO}_{2} \mathrm{G} 3 \mathrm{M}(\mathrm{F})$. Inset: Absorption spectrum of the dye solutio

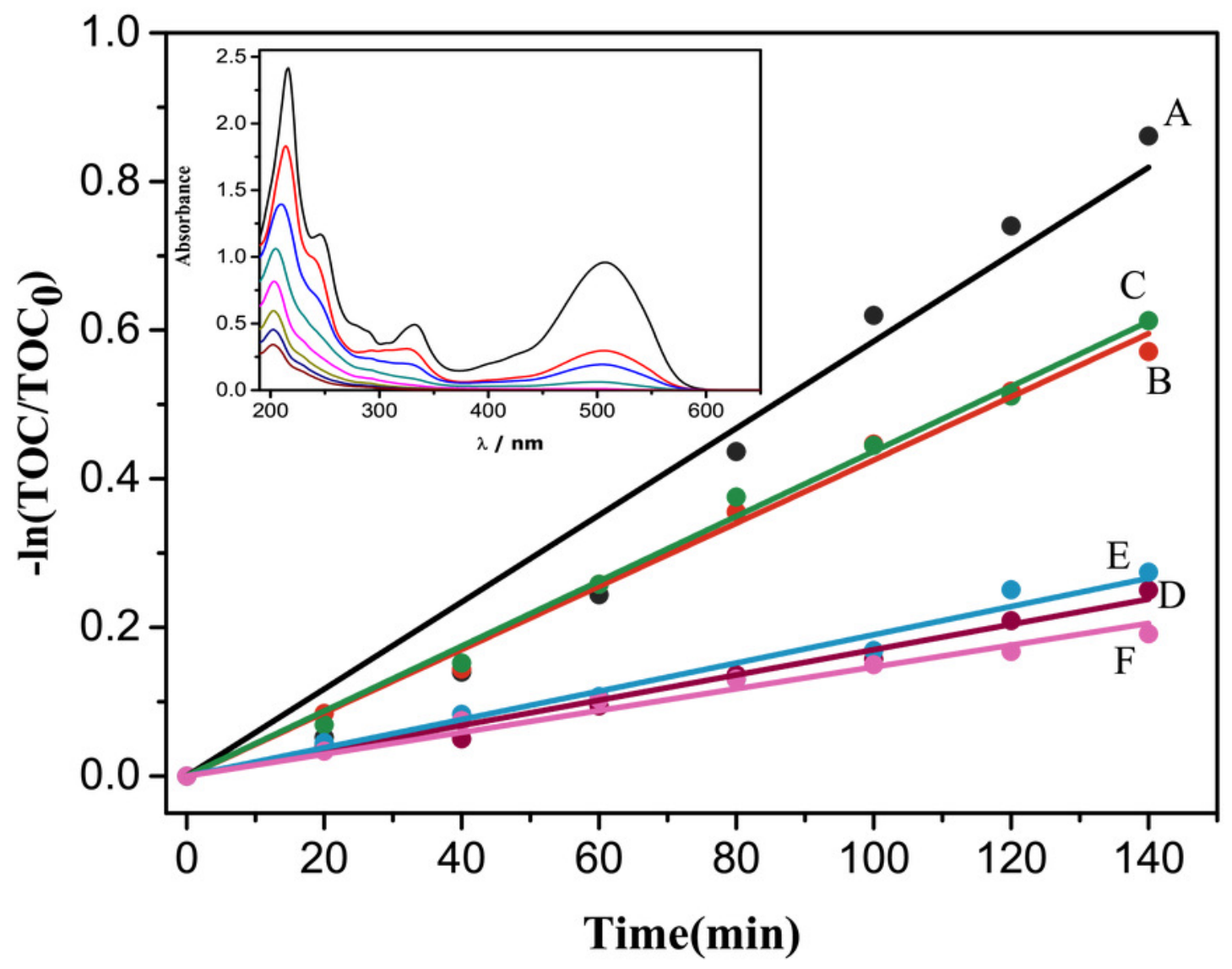




\section{Table $\mathbf{1}$ (on next page)}

Morphologic and electronic parameters to oxides synthesized. 


\begin{tabular}{ccccc}
\hline Photocatalysts & $\begin{array}{c}\text { Surface area } \\
\left(\mathbf{m}^{\mathbf{2}} \mathbf{g}^{-\mathbf{1}}\right)\end{array}$ & Porosity $(\mathbf{\%})$ & $\boldsymbol{E}_{\boldsymbol{g}}(\mathbf{e V})$ & $\boldsymbol{E}_{\boldsymbol{g}(\text { real })}(\mathbf{e V})$ \\
\hline $\mathrm{TiO}_{2} \mathrm{G} 1 \mathrm{HT}$ & $240.0 \pm 4.7$ & 30.6 & 3.30 & 2.64 \\
$\mathrm{TiO}_{2} \mathrm{G} 2 \mathrm{HT}$ & $158.5 \pm 2.9$ & 27.8 & 3.23 & 2.87 \\
$\mathrm{TiO}_{2} \mathrm{G} 3 \mathrm{HT}$ & $161.2 \pm 2.4$ & 25.1 & 3.28 & 3.05 \\
$\mathrm{TiO}_{2} \mathrm{G} 1 \mathrm{M}$ & $51.8 \pm 2.2$ & 12.4 & 3.27 & 2.86 \\
$\mathrm{TiO}_{2} \mathrm{G} 2 \mathrm{M}$ & $90.4 \pm 2.3$ & 12.3 & 3.25 & 3.00 \\
$\mathrm{TiO}_{2} \mathrm{G} 3 \mathrm{M}$ & $74.6 \pm 1.8$ & 14.1 & 3.24 & 3.01 \\
\hline
\end{tabular}




\section{Table 2 (on next page)}

Mineralization, Langmuir-Hinshelwood kinetics and discoloration of the P4R azo-dye mediated by the prepared oxides. 


\begin{tabular}{cllllll}
\hline & $\mathrm{TiO}_{2}$ & $\mathrm{TiO}_{2}$ & $\mathrm{TiO}_{2}$ & $\mathrm{TiO}_{2}$ & $\mathrm{TiO}_{2}$ & $\mathrm{TiO}_{2}$ \\
& $\mathbf{G 1 H T}$ & $\mathbf{G 2 H T}$ & $\mathbf{G 3 H T}$ & $\mathbf{G 1 M}$ & $\mathbf{G 2 M}$ & $\mathbf{G 3 M}$ \\
\hline $\begin{array}{c}\text { Mineralization } \\
(\%)\end{array}$ & 58 & 44 & 46 & 23 & 24 & 17 \\
$\begin{array}{c}(\%) \\
\mathrm{k}_{\text {app }} /\end{array}$ & 5.9 & 4.3 & 4.4 & 1.7 & 1.9 & 1.5 \\
$\left(\times 10^{3} \mathrm{~min}^{-1}\right)$ & & & & & & \\
$\begin{array}{c}\text { Discoloration } \\
(\%)\end{array}$ & 100 & 100 & 100 & 70 & 74 & 67 \\
\hline
\end{tabular}

